LIAMES, Campinas, SP, v. 19, 1-24, e019013, 2019

\title{
What do oranges and hammers have in common? The classifier 'round' in Wa'ikhana and other East Tukano languages
}

\author{
Kristina Balykova \\ Federal University of Rio de Janeiro, Brazil \\ https://orcid.org/0000-0001-6194-8821
}

\begin{abstract}
East Tukano languages are known for their developed nominal classification systems. Wa'ikhana (Piratapuyo) is in this sense a typical member of the family, since it has an open system with a large number of classes and with class markers which exercise derivational and agreement functions. Among all the Wa'ikhana inanimate classes, the class 'round' stands out for its semantic and morphosyntactic features. It is one of the most (if not the most) extensive classes, which includes round objects as well as objects of less prototypical shapes. Its markers in non-plural number have the biggest number of allomorphs, even though allomorphy of classifiers is not typical for this language. Besides, the class 'round' has a distinct plural marker, another feature absent from most classifiers. Comparison between Wa'ikhana and other related languages demonstrates that these peculiarities are shared by many East Tukano languages. Thus, the present paper aims to describe the class 'round' in Wa'ikhana and other languages of the family, and to show their common features as well as the features that distinguish Wa'ikhana.
\end{abstract}

KEYwORDS: Wa'ikhana; East Tukano; Nominal classification.

RESUMo: As línguas Tukano Oriental são conhecidas por seus sistemas de classificação nominal bem desenvolvidos. Nesse sentido, o Wa'ikhana (Piratapuyo) é um representante típico da família, pois possui um sistema aberto com grande número de classes, cujos marcadores exercem as funções de derivação e de concordância. Entre todas as classes inanimadas do Wa'ikhana, a classe 'redondo' se destaca por suas características semânticas e morfossintáticas. Ela é uma das mais (se não a mais) abrangente, incluindo tanto os objetos redondos como objetos de formatos menos prototípicos. Seus marcadores no número não-plural possuem a maior quantidade de alomorfes, sendo que a alomorfia nos classificadores não é típica para essa língua. Além disso, a classe 'redondo' apresenta um marcador distinto no plural, o que tampouco se verifica na maioria dos outros classificadores. A comparação do Wa'ikhana com as demais línguas da família Tukano Oriental mostra que essas peculiaridades são compartilhadas por muitas delas também. O presente artigo se propõe, então, a descrever a classe 'redondo' no Wa'ikhana e em outras línguas da família, demonstrando as características comuns assim como as que distinguem o Wa'ikhana.

PALAVRAS-CHAVE: Wa'ikhana; Tukano Oriental; Classificação nominal.

\section{Introduction}

This paper describes semantic and morphosyntactic properties of the inanimate class 'round', which presents many uncommon characteristics when compared to other 

inanimate classes, in Wa'ikhana and other related languages. ${ }^{1}$ The Wa'ikhana language pertains to the East Tukano (ET) family ${ }^{2}$ and was traditionally spoken at the Papuri river, on the border between Brazil and Colombia. Nowadays, many of its Brazilian speakers reside in the multiethnic settlement Iauaretê and in the towns of São Gabriel da Cachoeira and of Santa Isabel do Rio Negro, in the state of Amazonas. WA'I is an endangered language, rarely transmitted to children. According to the last Brazilian populational census carried out in 2010, there are 1401 Wa'ikhana in the country. Among them, only 81 people (less than 6 percent) speak the native language at home and only 10 speakers were under the age of 15 at the time of the census (IBGE 2010: Table 1.13).

WA'I is an ov language. The position of subject varies depending on discourse context (Stenzel \& Cezario 2019: 388). It has two major lexical classes: nouns and verbs. Property concepts are codified mostly by verbs and, to a lesser degree, by nouns (Balykova 2019: 133ff). ${ }^{3}$ Like in other ET languages, WA'I verbs receive evidential suffixes and can participate in serializations. The most characteristic feature of WA'I nouns is nominal classification. Another interesting feature is a distinction between non-plural and plural numbers. The non-plural number includes one, two, three or four entities and differs from the paucal number due to the incorporation of the singular.

The second chapter of this paper is a brief description of the WA'I inanimate nominal classification system. In $\S 3$, I address the semantics of the WA'I classifier - $g a$ 'round' and of related suffixes from other ET languages. The majority of these languages have classifiers which are - $g a$ cognates and cover similar semantic fields. The only exceptions are DES and SIR, which do not have - $g a$ cognates, and RET and TAN, in which probable - $g a$ cognates exercise a different function. In $\S 4$, I describe the allomorphs of the non-plural classifier 'round' in WA'I and other ET languages. $\S 5$ is dedicated to the possible - $g a$ cognates in RET and TAN and the relation they may have with the classifier 'round'. In $\S 6$, I address the morphemes which mark the plural of the class 'round' in WA'I and other ET languages. $\S 7$ contains the conclusions.

1 This material is based upon work supported by the National Science Foundation (Documenting Endangered Languages Program) under Grant No. BCS- 1664348 "Grammar and multilingual practices through the lens of everyday interaction in two endangered languages in the East Tukano family" (2017-2020), under PI Kristine Stenzel.

${ }^{2}$ Other languages of this family are Kotiria (Wanano), Tuyuka, Yuruti, Pisamira, Karapana, Bará, Tatuyo, Tukano, Tanimuka/Retuarã, Yahuna, Barasana, Eduria (Taiwano), Makuna, Desano, Siriano, Yupua and Kubeo (Chacon 2014: 282). Yahuna e Yupua are extinct and are not considered in this paper. Barasana e Eduria (Taiwano) can be considered dialects of the same language (Jones \& Jones 1991: 1-2). Besides, I have not found any relevant information on Bará.

I will refer to the languages mostly by the first three letters of their names.

${ }^{3}$ Classifiers also can express properties, mainly, shapes. For example, in WA'I the noun $\sim$ tta 'stone' receives the classifier - $g a$ 'round', when the referent is a stone, which resembles a sphere, and - $p a$ 'flat.2D', when the upper surface of the referred stone is flat. Similarly, the noun vidru 'glass' receives the classifier - $g a$ 'round' to denote a bottle of the traditional round shape, whereas the same noun with the classifier - pa 'ta 'flat.3D' denotes rectangular bottles, sometimes used by the producers of alcoholic drinks. A more in-depth study of this function of classifiers is still to be done. 


\section{Wa'ikhana inanimate nominal classification system}

According to Grinevald \& Seifart (2004: 279), western Amazonian languages share an areal feature of including "large, open systems of nominal classification that have agreement functions to varying degrees, on the one hand, and serve a derivational function on nouns, on the other hand". In this section, I will describe how the mentioned characteristics - big size, openness, derivational function and agreement function - are presented in the WA'I inanimate nominal classification system. I will also address the relation between this system and the grammatical number.

\subsection{Size}

A comprehensive list of WA'I classifiers is still nonexistent. In Table 1, I list 18 most frequent inanimate classifiers from my fieldwork data. All of them share the property of not being able to function as independent nouns.

Table 1: Some Wa'ikhana inanimate classifiers

\begin{tabular}{c|c}
\hline Classifier & General meaning \\
\hline$-b e^{\prime} t o$ & ring-like \\
\hline$-g a /-k a /-a /-d i a$ & round \\
\hline$-d a$ & thread-like \\
\hline$-d o$ & concave \\
\hline$-d o$ & miscellaneous ${ }^{4}$ \\
\hline$-g u /-d \boldsymbol{t}$ & tree-like \\
\hline$-k o$ & liquid \\
\hline$-k u e$ & slice \\
\hline$-p a$ & flat.2D \\
\hline$-p a{ }^{\prime} t a$ & flat.3D \\
\hline$-p a d o$ & curved \\
\hline$-p e$ & seed \\
\hline$-\sim p h i^{5}$ & blade-like \\
\hline$-\sim p u$ & leaf-like \\
\hline$-s t u^{6}$ & pot \\
\hline$-\sim t o$ & bunch \\
\hline$-t u h u$ & pile \\
\hline$-\sim y o$ & palm \\
\hline &
\end{tabular}

${ }^{4}$ The predominant semantics of the members of this class is not clear yet. Nevertheless, there are morphosyntactic grounds (explained further) to distinguish the classifiers - $d o$ 'concave' and - $d o$ 'miscellaneous'.

${ }^{5}$ The tilde $\sim$ before a morpheme indicates that it is nasal.

${ }^{6}$ This classifier is a reduction of the noun suhtu 'pot', still used in the language. 


\subsection{Openness}

The WA'I inanimate nominal classification system is open, since the list of nouns assigned to a semantic class can always be increased by new items. In particular, the membership is open to loanwords from Portuguese and Spanish. For example, the class 'round' includes fruits and vegetables brought by the non-Indians, such as wiriboa (from Port. limão 'lime'), senora (from Port. cenoura 'carrot'), pepino (Port. 'cucumber'). Some loanwords can enter more than one class, since they have several meanings in the source language. For example, the Portuguese noun vela means 'candle' as well as 'spark plug'. When a Wa'ikhana uses it as a loanword in its first meaning, vela is assigned to the class 'tree-like' (1a). But when it is used in the second meaning, vela enters the class 'round' (1b).

$\begin{array}{cl}\text { (1) a. } p \text { tadut } & \text { vela } \\ \text { pua-dut } & \text { vela } \\ \text { two-CLF:tree.NPL } & \text { candle } \\ \text { 'two candles' } & \\ & \\ \text { b. akaria } & \text { vela } \\ \text { aka-dia } & \text { vela } \\ \text { one-CLF:round.NPL } & \text { spark.plug } \\ \text { 'one spark plug' } & \end{array}$

Furthermore, the list of classifiers also constantly grows. The main source for new classifiers is nouns. When an independent noun occurs in the classifier slot to classify itself, it is called a repeater (Aikhenvald 2000: 103). In (2), the noun deko 'day' functions as a repeater. This is an initial stage of the possible transformation from a noun to a classifier. Like in other ET languages, the grammaticalization of a repeater into a classifying suffix is accompanied by the reduction of its phonological structure, simplification of tonal and nasal properties, and semantic extension (Gomez-Imbert 2007: 408-9, 422). The productivity and openness of the WA'I nominal classification system is further manifested by the fact that even loanwords can function as repeaters (3).

(2) dehko ke'noaridehko ihide
deko $\sim$ ke'doa-di-deko
ihi-de
day be.good-NMLZ.3NPL-RP:day
COP-VIS.IPFV. $2 / 3$
'It is a good day.'

7 The first line of the transcription of the WA'I data is its orthographic form, the second one is the phonological form. The pronunciation of the phoneme /d/ varies between $[\mathrm{d}]$ and $[\mathrm{r}]$, which is reflected in the orthography. Unvoiced consonants at the onset of non-initial syllables are pre-aspirated, which is represented by $<\mathrm{h}>$ in the orthographic form. This pre-aspiration is not phonological. WA'I is a tonal language, but I do not indicate the high and low tones, since I do not discuss phonological features of the classifiers.

The abbreviations used in this paper and absent in the Leipzig Glossing Rules (https://www.eva.mpg.de/lingua/ pdf/Glossing-Rules.pdf) are ANPH 'anaphoric', CONT 'countable', DIM 'diminutive', EXORT 'exhortative', RP 'repeater' and vIs 'visual'. 
(3) puasaku arususakuride nekataya pua-saku arusu-saku-di-de two-RP:sack rice-RP:sack-PL-OBJ $\sim d e-k a-a^{\prime} t a-y a$ 'Fetch two sacks of rice!'

take-DUR-come-IMP

\subsection{Derivational function}

A common feature between different nominal classification systems of the northwestern Amazonia is a highly productive derivational use of classifiers, which can be attached to nouns or (nominalized) verbs to produce new nouns (Aikhenvald 1994: 436-9; Epps 2007: 114-118, 121; Grinevald \& Seifart 2007: 265-7). This function is also characteristic of the WA'I classifiers. One of the best examples illustrating the derivational function of classifiers is their use with nouns denoting plants. Whereas an unclassified noun denotes a plant in a generic way or indicates an unspecified quantity of its fruits, different classifiers attached to the noun derive names for different parts of the plant or results of its processing, such as juice, (4) - (6).

(4) a. urẽto

$\sim$ ture- to

pupunha-CLF:bunch

'bunch of pupunha fruits'

(5) b. puhpiagu

pupia-gz

ucuqui-CLF:tree

'ucuqui tree'

(6) a. ihkitõ

iki- to

inajá-CLF:bunch

'bunch of inajá fruits' b. $u r e \tilde{k} o$

$\sim$ ure-ko

pupunha-CLF:liquid

'pupunha juice'

b.puhpiako

pupia-ko

ucuqui-CLF:liquid

'ucuqui juice'

b. ihkiño

$i k i-\sim y o$

inajá-CLF:palm

'inajá palm'

Classifiers are suffixed directly on underived nominal roots (7a). Most classifiers cannot be attached to verbal roots directly and need to be preceded by the nominalizers $-d i$, which derives count nouns in the non-plural (7b), or $-y e$, which derives count nouns in the plural $(7 \mathrm{c})$ as well as mass and abstract nouns.
(7) a. pohoada
pohoa-da
b.yo'yerida
tucum.fiber-CLF:thread
yo'ye-di-da
'tucum fiber thread'
to.fish-NMLZ.3NPL-CLF:thread
'fishing line'
c. peyedari
peya-ye-da-di
be.many-NMLZ.3NPL-CLF:thread-PL
'many threads'


The only classifiers with a nominalizing function are - $d o$ 'miscellaneous' (8a) and $-d \boldsymbol{t}^{8}$ 'tree-like' (8b), an allomorph used on verbal roots.

(8) a. kamisa ñiino

kamisa

shirt

'black shirt' ryii-do a'ba-dut

be.black-CLF:miscel. be.rotten-CLF:tree.NPL

'rotten tree'

\subsection{Agreement function}

Some authors have already called attention to the agreement function of classifiers in ET languages (Gomez-Imbert 2007: 403-406 for TAT; Coutinho-Silva 2014: 167-8 for кот) and other languages of the northwestern Amazonia (Aikhenvald 1994 for Tariana; Grinevald \& Seifart 2007: 267-9 for Miraña). The WA'I classifiers can also function as agreement markers. When a WA'I noun is classified, the corresponding classifier (or repeater) can be attached to any coreferential element, such as deverbal modifiers, demonstratives and numerals. In the examples (9) - (12), classifiers are used as agreement markers on a deverbal noun, the anaphoric pronoun $t i$, the possession marker yaa and a numeral, respectively.

(9) yu'u di'iphĩ siwariphĩ kut
yt' 't di' $i-\sim p h i$
siwa-di- $\simeq$ phi
$k t a-t t$
1SG meat-CLF:blade
be.sharp-NMLZ.3NPL-CLF:blade have-VIS.PFv.1
'I had a sharp knife.'

(10) tipa uhtãpapu i'yษna

$\begin{array}{lll}\underline{t i-p \boldsymbol{a}} & \sim \boldsymbol{t t a}-\boldsymbol{p a}-\boldsymbol{p u} & i^{\prime} y \boldsymbol{z}-\sim d a \\ \text { ANPH-CLF:flat.2D } & \text { stone-CLF:flat.2D-LOC } & \text { eat-EXORT }\end{array}$

'Let's eat on this flat stone!'

(11) biastu tikodo yaastu moayuayz'duari

$\begin{array}{llll}\text { bia-stu } & t i-k o-d o & \text { yaa-stu } & \sim \text { boayua-yz'dt-a-di } \\ \text { pepper-CLF:pot } & \text { ANPH-F-3NPL } & \text { POSS-CLF:pot } & \text { be.salted-pass-?-VIS.PFV.2/3 } \\ \text { 'This woman's quinhapira (a dish made of fish and chili) was too salted.' }\end{array}$

(12) yz't akaro su'tiro duu

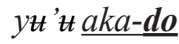
su'ti-do
$d u-u$
1SG one-CLF:miscel. clothes-CLF:miscel.
buy-VIS.PFV. 1
'I have bought one piece of clothing.'

Nevertheless, classifiers can also be omitted. An investigation on semantic, grammatical and discourse grounds of such omissions is still to be conducted. So far, it is

\footnotetext{
${ }^{8}$ My hypothesis is that this form has originated from the fusion of the nominalizer - $d i$ and the classifier $-g t$, in which $/ \mathrm{g} /$ has dropped. 
clear that a few classifiers are not used as agreement markers. The classifier - $k o$ 'liquid' never occurs on deverbal nouns. When these refer to liquids, they are simply derived by the nominalizer $-y e$, used to produce mass nouns (13). Perhaps, the reason is that the use of a classifier on deverbal nouns also has a unitizing function, which is incompatible with the mass semantics of nouns for liquids.

(13) kantko yuhstayede si'nii

$\begin{array}{lll}\sim k \text { kadtu-ko} & \text { yusta-ye-de } & \sim s i ' d i-i \\ \text { sugarcane-CLF:liquid } & \text { be.cold-NMLZ.3PL-OBJ } & \text { drink-VIS.PFV.1 } \\ \text { 'I drank cold sugarcane juice.' } & \end{array}$

The classifier - $d o$ 'concave' is atypical, because it marks only the underived noun functioning as the NP head. The other NP elements receive this underived nominal root, like bati 'basket' in (14), or another classifier compatible with the semantics of the noun, like - $p a$ 'flat.2D' in (15), in the classifier slot. In fact, this is the difference between the -do 'concave' and the - $d o$ 'miscellaneous' which functions as an agreement marker.

(14) yz' 'u bahtido wa'mabahti duu

$\begin{array}{llll}y_{\boldsymbol{H}}^{\prime} \boldsymbol{t} \boldsymbol{b} & \text { bati-do } & \sim \text { wa'ba-bati} & d u-u \\ 1 \mathrm{SG} & \text { basket-CLF:concave } & \text { new-RP:basket } & \text { buy-VIS.PFV.1 }\end{array}$

'I have bought a new basket.'

(15) wahpado ya 'saripa o'oya

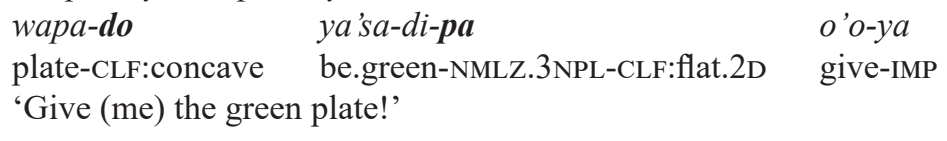

\subsection{Number and inanimate classifiers}

In most cases, the plural forms of inanimate classified nouns are derived by the attachment of the suffix - $d i$, as shown in (16) and (17).

(16) a

a. ihkipe
iki-pe
inajá-CLF:seed
'inajá seed'

(17)

$$
\begin{aligned}
& \text { a. } \text { t'setõ } \\
& \text { u'se- } \text { to } \\
& \text { cucura-CLF:bunch } \\
& \text { 'bunch of cucura fruits' }
\end{aligned}
$$

b. ihkiperi

iki-pe-di

inajá-CLF:seed-PL

'(many) inajá seeds'

Number distinction is also found on nominalizers used with verbal roots. Whereas the suffix -di derives nouns in non-plural form, like ape-di-pa '(football) field' in (18a) 
and $\sim y a i-d i-\sim p u$ 'dry leaf' in (19a), the deverbal nouns in plural are derived by the suffix $-y e$, like ape-ye-pa-di '(football) fields' in (18b) and $\sim y a i-y e-\sim p u-d i$ 'dry leaves' in (19b).

(18) a. di'iga

di' $i-g a$

rubber-CLF:round.NPL

'football field'

b. di'iga

di'i-ga

rubber-CLF:round.NPL

'(many) football fields' ahperipa

ape-di-pa

play-NMLZ.3NPL-CLF:flat.2D

ahpeyepari

ape-ye-pa-di

play-NMLZ.3PL-CLF:flat.2D-PL
(19) a. $\tilde{n}$ airip $\tilde{u}$

$$
\begin{aligned}
& \sim \text { yai-di- } \boldsymbol{p u} \\
& \text { be.dry-NMLZ.3NPL-CLF:leaf } \\
& \text { 'dry leaf' }
\end{aligned}
$$
b. ñaiyepũri
$\sim y a i-y e-\sim p u-d i$
be.dry-NMLZ.3PL-CLF:leaf-PL
'(many) dry leaves'

There are only two inanimate classes which have distinct markers in non-plural and plural forms: the class 'round' with plural marker -poka (20) and the class 'tree-like' with plural marker $-y u k u(21)$, which is also the word for 'tree'.
(20) a. uhtãga
$\sim$ tha-ga
b. uhtãpohka
stone-CLF:round.NPL
uta-poka
'stone'
stone-CLF:round.PL
'(many) stones'
(21) a. bu'sagu
bu'sa-gut
cotton-CLF:tree.NPL
'cotton tree'
b. bu'sayuhkt
bu'sa-yukt
cotton-CLF:tree.PL
'(many) cotton trees'

\section{Semantic content of the classes marked by - $g a$ cognates in ET languages}

The class 'round' in WA'I is perhaps the most extensive of all inanimate classes. It includes nouns which denote sphere-shaped objects of any material (e.g. paper ball or thread ball), fruits (e.g. orange, pineapple, cubiu, achiote, cassava tuber), vehicles (e.g. canoe, car and airplane), tools (e.g. hammer, cassava grater called caititu, some fish traps) and other objects (e.g. bottle, bulb, torch or spark plug). The shapes of some of these objects are actually identical or quite similar to spheres, while others are oblong or cylinder like. The third group comprises objects which have no round dimension at all, such as caititu cassava grater, introduced by the non-Indians (cf. Figure 1). ${ }^{9}$

${ }^{9}$ One of the reviewers proposed that the class could be called '3D (with no specified shape)', given the heterogeneity of its members. However, I prefer to maintain the name 'round' in order to emphasize that the 


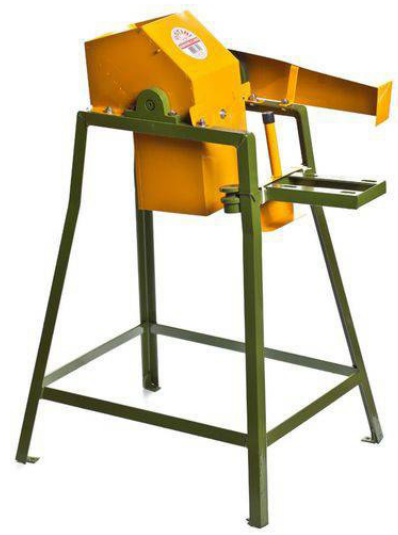

Figure 1: Caititu cassava grater ${ }^{10}$

In most other ET languages, the semantic scope of the - ga cognates is equally vast. The corresponding class normally includes sphere-shaped objects in general, fruits and tubers, body parts and other objects, such as ax (TAT, Gomez-Imbert 2007: 419), outboard motor (TUY, Barnes 1990: 275) or fish trap (BAR, Jones \& Jones 1991: 12). Nevertheless, the semantic domains covered by the - $g a$ cognates are not exactly the same for all considered ET languages. For example, the cognates often mark nouns denoting vehicles, as in BAR, KOT, MAK, PIS, TAT, and WA'I, but in TUY and TUK the nouns for canoe, car and airplane enter the class of items with hollow interiors marked by a non-cognate -wi (Barnes 1990: 278; Ramirez 1997: 213). Another example are nouns denoting some oblong fruits, such as banana. In MAK the noun for banana is included in the class of round objects, whereas in KOT, TUK, TUY and WA'I it enters the class of curved objects, marked by the classifier -poro/-paro/-pado, and in KAR and TAT it receives the classifier -ro.

It is also worth noting that, although in most ET languages the - $g a$ cognates are the main classifiers for round objects, in Kubeo it occupies a more peripherical position. In this language the classifier $-k a$ occurs with a quite limited set of nouns, such as the nouns for nose, ear, manioc tuber, chili, stool, triangular bag and fishnet, whereas most of the three-dimensional objects are covered by the classifiers $=b o$ 'oval' and $=d \dot{t}$ 'round' (Chacon 2012: 248).

\section{Allomorphs of the non-plural marker of the class 'round'}

Even though allomorphy is not typical for most WA'I classifiers, the non-plural classifier 'round' has four variants: $-g a,-k a,-a$ and $-d i a$. As I propose in Balykova (2019: 119), the distribution of these allomorphs has morphosyntactic and lexical grounds demonstrated in Table 2 below.

objects of round shape are prototypical members of the class, whereas other objects, such as hammer or cassava grater, are included by processes of extension, in particular, the process of chaining, "based on sets of local analogies that create disjunctive classes with no identifiable common feature" (Grinevald 2000: 1018).

${ }^{10}$ Source: https://images-americanas.b2w.io/produtos/01/00/oferta/42826/4/42826427 1GG.jpg. 
Table 2: Distribution of allomorphs of the WA'I classifier 'round' in non-plural number

\begin{tabular}{c|c}
\hline Allomorph & Lexical (sub)class / lexeme \\
\hline$-g a$ & underived nouns \\
\hline$-k a$ & demonstratives \\
\hline$-a$ & deverbal nouns \\
\hline$-d i a$ & $\begin{array}{l}\text { numerals, possession marker yaa, nouns } \\
b \boldsymbol{t} k t \text { 'old (one)' and } \sim \text { wabt 'new (one)' }\end{array}$
\end{tabular}

In WA'I there are some underived nouns which are never openly marked for the class they are included in, although their coreferential expressions do receive classifiers, which function as agreement markers. These can be nouns for traditional objects (e.g. $y \mathfrak{u k t s a}$ 'canoe') as well as loanwords (e.g. martelo 'hammer' or naraña/laranja 'orange'). However, if an underived noun can receive a classifier and is classified as 'round' in a given context, it always receives the allomorph - $g a$. This suffix is often combined with names for plants, deriving nouns which denote fruits of those plants (22), or with names for materials, deriving nouns which denote round objects made of that material (23).

(22)
a. buhsiaga
busia-ga
achiote-CLF:round.NPL
'achiote fruit'
c. ktga
$k \boldsymbol{k t} \boldsymbol{g a}$
cassava-CLF:round.NPL
'cassava tuber'

(23) a. pohoaga

pohoa-ga

tucum.fiber-CLF:round.NPL

'ball of tucum fiber' b. ehtoaga

etoa-ga

cubiu-CLF:round.NPL

'cubiu fruit'

d. senag ã

rseda-ga

pineapple-CLF:round.NPL

'pineapple fruit'

b. vidruga

vidru-ga

glass-CLF:round.NPL

'bottle'

If a noun is derived from a verb by the nominalizer - $d i$ and is classified as 'round', it is marked by the allomorph $-a$. Some of these nouns are used to denote specific objects, as in (24). These nouns are usually derived from active verbs and function as NP heads.

(24) a. si'ória

$\sim$ si'o-di-a

light.up-NMLZ.3NPL-CLF:round.NPL

'bulb, torch' 
b. wa'teria

wa'te-di-a

polish-NMLZ.3NPL-CLF:round.NPL

'stone for polishing pottery'

c. ku ohseria

ku ose-di-a

cassava grate-NMLZ.3NPL-CLF:round.NPL

'caititu cassava grater'

Nominalized active verbs can also function as head modifiers, as shown in (25).

(25) a. sena parẽria

$\sim$ seda $\quad \sim$ pare-di-a

pineapple peel-NMLZ.3NPL-CLF:round.NPL

'peeled pineapple'

b. yz'z kahsa kũria

yн'z kasa $\sim \boldsymbol{k u}$-di-a

1sG matapi put-NMLZ.3NPL-CLF:round.NPL

'the matapi (fish trap) which I have put.'

Nouns derived from descriptive verbs generally occur as modifiers in NPs (26).

(26) a. $y \mathrm{u} h k \mathrm{u}$ sa pahiria

yuktsa pahi-di-a

canoe be.big-NMLZ.3NPL-CLF:round.NPL

'big canoe'

b. laranja buhtiria

laranja buti-di-a

orange be.ripe-NMLZ.3NPL-CLF:round.NPL

'ripe orange'

Numerals from one to three (27a) - (29a), the possession marker yaa (30a), as well as nouns $\sim w a$ ' $b a$ 'new (one)' (31a) and bukt 'old (one)' (32a) receive the allomorph -dia. This suffix is homophone to the sequence $-d i$ 'nominalizer' $+-a$ 'round', which were observed in the deverbal nouns above. Nevertheless, -dia is not analyzable as two separate suffixes when attached to numerals, the possession marker, and nouns $\sim w a$ ' $b a$ 'new (one)' and $b u k u$ 'old (one)', since these do not require the use of the nominalizer before classifiers (or repeaters), as the examples $(27 b)-(32 b)$ show.

(27) a. akaria

aka-dia

one-CLF:round.NPL

'one round object' b. akatõ aka- to one-CLF:bunch 'one bunch' 
(28) a. puaria

\section{pua-dia}

two-CLF:round.NPL

'two round objects'

(29) a. ihtiaria

\section{itia-dia}

three-CLF:round.NPL 'three round objects'

(30) a. yaaria

$$
\text { yaa-dia }
$$

POSS-CLF:round.NPL 'my round object'

(31) a. wa'maria

$\sim$ wa'ba-dia

new-CLF:round.NPL

'new round object'

(32) a. bukuria

bukt-dia

old-CLF:round.NPL

'old round object' b. puapa

\author{
рнa-pa \\ two-CLF:flat.2D \\ 'two flat objects (e.g. plates)'
}

b. itiada

itia-da

three-CLF:thread

'three thread-like objects (e.g. wires)'

b. yaaphĩ

yaa- phi

POSS-CLF:blade

'my knife'

b. wa'mawu

$\sim w a^{\prime} b a-w \boldsymbol{t}$

new-RP:building

'new building (e.g. house)'

b. bukuwut

bukt-wu

old-RP:building

'old building (e.g. house)'

кОт has a cognate allomorph -ria, which occurs on number modifiers (33).

(33) kũria buhsóka

$\begin{array}{ll}\sim k u ́ \text {-ríá } & \text { busó-ka } \\ \text { one-CLF:round } & \text { canoe-CLF:round } \\ \text { 'one canoe; a canoe' (Stenzel 2013: 178, ex.13c) }{ }^{11}\end{array}$

According to Stenzel (2013: 177), some deverbal nouns also receive this allomorph, e.g. wz-ria 'airplane' and phuti-ria 'tubular flute'. Therefore, the classifier -ria would also have a nominalizing function, given that the nouns in question are derived from the verbs $w z$ 'fly' and phuti 'blow', respectively.

The same analysis was proposed for cognate forms in WA'I. For example, in Stenzel \& Cezario (2019: 412) the deverbal noun for 'plane' is segmented as wuz 'fly' + -día

${ }^{11}$ When data are reproduced from other authors, I have changed some of their grammatical glosses to corresponding ones from the Leipzig Glossing Rules, e.g. abbreviations like CLS and CLSF have been changed to CLF 'classifier'. Furthermore, authors give different names to the - ga cognates, e.g. 'plump', 'hollow', 'having a hole', 'three-dimensional' etc. In order to uniformize the glosses, I use 'round' as the common name for the - $g$ a cognates, since all of them mark round objects. I have also translated the lexical glosses into English, when they were in Spanish or Portuguese. When the author does not gloss an example, I do it following the author's description. 
'round'. This analysis becomes arguable, if we consider nominalizations of the same roots involving other classifiers. If we segment the noun in (34a) as $\sim t u d u$ 'spin' and -dia 'round', then we would have to do the same in (34b), segment the noun in $\sim t u d u$ 'spin' and -dibe 'to 'ring'. But we know that the classifier is -be to (34c) and there is no reason to treat -dibe 'to as a single morpheme.

(34) a. tunuria

$\sim t u d u-\boldsymbol{d i}-\boldsymbol{a}$

spin-NMLZ.3NPL-CLF:round.NPL

'car'

c. ahkabe 'to

aka-be'to

one-CLF:ring

'one ring-like object' b. tunuribe'to

$\sim$ tudu-di-be'to

spin-NMLZ.3NPL-CLF:ring

'wheel'

The unusual thing about the allomorph $-a$ is that it only occurs on deverbal nouns. Nevertheless, we should recognize that it is a different allomorph, which follows the nominalizer $-d i$, in order to maintain the parallelism with other classifiers occurring on deverbal nouns.

Finally, demonstrative pronouns require the allomorph $-k a(35)$.

(35) sika vidru ya'saria

$\begin{array}{lll}s i-k \boldsymbol{a} & \text { vidru } & y a \text { 's } a-d i-a \\ \text { DEM.DIST-CLF:round.NPL } & \text { glass } & \text { be.green-NMLZ.3PL-CLF:round.NPL }\end{array}$

'that green bottle'

Other ET languages also do not exhibit allomorphy for most classifiers, the classifier 'round' being an exception. For example, in BAR there are three allomorphs: $-a,-k a$ and - $g a$. As the examples from Jones \& Jones (1991) show, $-a$ is used with underived nouns (36a-b), $-k a$ with deverbal ones (36c-d), whereas $-g a$ is attached to the possession marker ya (36e).

(36) a. kứbú-á

canoe-CLF:round

'canoe'

(Jones \& Jones 1991: 12, ex. 41)

c. $w z-r i-k \boldsymbol{a}$

fly-PTCP-CLF:round

'airplane'

(Jones \& Jones 1990: 21) b. arú-a

fish.trap-CLF:round

'fish trap'

$\begin{array}{lll}\text { e. } k \tilde{u} b u-a & y \boldsymbol{t} & y \boldsymbol{a}-\boldsymbol{g} \boldsymbol{a} \\ \text { canoe-CLF:round } & 1 \mathrm{sG} & \text { GEN-CLF:round }\end{array}$

'my canoe' (Jones \& Jones 1991: 50, ex.140) 
In TAT, the allomorphs are $-a$ and $-k a$. Gomez-Imbert (2007: 143) offers an exhaustive account of their distribution across and within different lexical classes. The allomorph $-a$ is the most widespread, being attached to underived nouns, numerals, the demonstrative $-t i$, the possession marker jáá and the lexemes wabá 'new' and bikit' 'old'. The scope of the allomorph $-k a$ embraces deverbal nouns and the deictic distal $(h) i$.

In MAK, the allomorphs are $-k a$ and $-g a$. The first one is used on deverbal nouns (37a), whereas the second one is used on underived nouns (37b), numerals (37c) and on the possession marker $(37 \mathrm{~d})$.

(37) a. witi-ri-ka

fly-PTCP-CLF:round

'airplane'

(Smoth., Smoth. \& Frank 1995: 35) (Smoth. \& Smoth. 1993: 177)

\section{c. hia-ga}

two-CLF:round

'two (balls, stones)' b. sẽna-g $\tilde{\boldsymbol{a}}^{12}$

pineapple-CLF:round

'pineapple'

(Smoth., Smoth. \& Frank 1995: 39) (Smoth., Smoth. \& Frank 1995: 41)

There are also some languages that do not exhibit allomorphy for the classifier in question. In PIS the suffix is always - $g a$, as we can judge from the examples involving an underived noun (38a), a deverbal noun (38b) and a demonstrative (38c).

(38) a. dika-ga

arms-CLF:round ${ }^{13}$

'an arm'

(Preciado 2018: 69, ex. 4.5.2.1.e) b. hĩa-di=ga

illuminate-NMLZ $=$ CLF:round

'light bulb'

(Preciado 2018: 44, ex.: 3.3.1.b)

\section{c. ati-ga- ga \\ this-CLF:round-DIM}

'this round and small one' (De Pérez 2000: 386)

In KUB, the only cognate form seems to be $-k a$, used with underived nouns, adjectives, deverbal nouns and demonstratives, as the example (39) shows.
(39) a. bia $=\boldsymbol{k} \boldsymbol{a}$
ira $=\boldsymbol{k} \boldsymbol{a}$
chili $=$ CLF:round
big $=$ CLF:round
'a big chili' (Chacon 2012: 228, ex. 7.4 a)
b. $b i a=k a \quad h \tilde{a} a-d i=k a$
chili $=$ CLF:round $\quad$ red-NMLZ $=$ CLF:round
'a red chili' (Chacon 2012: 228, ex. 7.4 b)

\footnotetext{
${ }^{12}$ The nasalization of the suffix is due to the spreading of the nasality from the root.

${ }^{13}$ Although the author glosses - $g a$ as 'inanimate individualizer' in this example, she admits that it is likely to be the same morpheme as the classifier 'round' - $g a$ (Preciado 2018: 71, footnote 42). 


\author{
c. $i=\boldsymbol{k a} \quad \tilde{u} e=\boldsymbol{k} \boldsymbol{a}$ \\ this $=$ CLF:round nose $=$ CLF:round \\ 'this nose' (Chacon 2012: 328, ex. 9.34 a)
}

As we can see from the examples, the variation $-k a /-g a /-a$ is present within as well as across the ET languages. The suffix $-a$ seems to derive from the $-g a$, in which the onset has elided. This process is observable synchronically in some ET languages, such as TUY (Barnes 1990: 280) and TUK (Chacon 2007: 168, ex. 13a).

What we do not find in other ET languages, aside from WA'I and кот, is the allomorph -dia/-ria. Probably, the origin of this allomorph on numerals and on the possession marker $y a a$ is due to analogical change. The sequence $-d i$ 'nominalizer' $+-a$ 'round' found on deverbal nouns should have been reanalyzed by speakers as a single suffix -dia (even though grammatically it is not). Given that deverbal nouns often occur as modifiers within NPs, the sequence perceived as a single suffix -dia was spread to other modifiers, such as numerals and the possession marker yaa.

With regards to the nouns buku 'old' and $\sim w a$ 'ba 'new', which also receive the allomorph -dia, the explanation is different. As I suggest in Balykova (2019: 172), unlike the numerals and the possession marker yaa, these two nouns have their diachronic origin in verbs, the suffix - dia being a relict form persisting since this verbal past. Nevertheless, buku 'old' and $\sim w a$ 'ba 'new' are synchronically underived nouns and the allomorph -dia occurring on them cannot be segmented in $-d i+-a$ anymore (Balykova 2019: 179-180).

\title{
5. The neuter marker $-a /-k a$ in Retuarã and Tanimuca: a possible -ga cognate
}

Strom (1992: 45-6) distinguishes four noun classes in RET: neuter nouns (inanimate or nonhuman), human singular masculine nouns, human singular feminine nouns and human plural nouns. TAN has a very similar system (Eraso 2015: 174). The suffixes that mark each class in both languages are presented in the Table 3 below.

Table 3: Noun classes in Retuarã and Tanimuca

\begin{tabular}{c|l|c|c}
\hline \multirow{2}{*}{ Class } & \multicolumn{2}{|c|}{ Semantic content } & \multicolumn{2}{c}{ Markers } \\
\cline { 3 - 4 } & & RET & TAN \\
\hline Class 1 & inanimate or nonhuman animate nouns, & $-a /-k a$ & $-a /-k a$ \\
& both singular and plural & & \\
\hline Class 2 & human singular masculine nouns & $-i /-k i /-h \tilde{\imath}$ & $-i /-k i$ \\
\hline Class 3 & human singular feminine nouns & $-o /-k o$ & $-o /-k o$ \\
\hline Class 4 & human plural nouns & $-r \tilde{a} /-h \tilde{a} /-h a$ & $-r \tilde{a}$
\end{tabular}

In RET, the suffixes $-a$ and $-k a$, which mark Class 1 , occur with all nonhuman nouns or adjectives, whether they are functioning as heads, modifiers or copula complements. The only restriction is that a modifier of a definite head does not receive the marking (Strom 1992: 23). In (40), we see a sentence where both the adjective (modifier) and the 
noun (an indefinite head) are marked by $-a /-k a$. In TAN, the absence of the neuter marker on adjective also means that the head is definite (Eraso 2015: 244-5), as shown in (41).

(40) ho?ba-ka kubũ-yapu-a dã-bõ?a-yu

big-N canoa-tree-N 3PL-search-PRS

'They are searching for a big canoe tree' (Strom 1992: 24, ex. 72)

(41) a. hó 'ba-ó-ká

big-CLF:round-N pepper-N

'a big round pepper'

(Eraso 2015: 245, ex. 205a and 205b) $\begin{array}{cl}\text { b. hó 'ba-ó } & \text { biá- } \varnothing \\ \text { big-CLF:round } & \text { pepper-N } \\ \text { 'the big round } & \text { pepper' }\end{array}$

With respect to the $-a /-k a$ allomorphy, Strom does not specify its conditions, but supposes that diachronically the variation could have been $-g a \sim-k a$, but the $/ * \mathrm{~g} /$ was unstable and has disappeared in some Tukanoan languages (Strom 1992: 46, footnote 21). ${ }^{14}$ This variation corresponds to what we observe in the allomorphs of the - $g a$ 'round' cognates across ET languages.

Gomez-Imbert (2007: 421) already noted that the marker $-a /$-ka in RET (and we can add, in TAN) seems to be a cognate of the 'round' class marker in TAT (and, as a consequence, in other ET languages). If they are indeed cognates, the question is whether the classifier 'round' has grammaticalized into the neuter marker in RET and TAN (hypothesis 1) or, conversely, whether the neuter marker has turned into the classifier 'round' in most ET languages (hypothesis 2). I will try to answer this by arguing against the first hypothesis.

There is evidence that classifiers for round objects can actually acquire a broader meaning and begin to function as default classifiers. Greenberg (1972: 34-5) notes that general classifiers present in some languages often originate from a shape classifier, most typically the one used for round objects. In this process the classifier undergoes semantic generalization "to the point at which it not only cooccurs itself with a very large and heterogeneous group of nouns, but may be used as an alternative to almost any other classifier".

Aikhenvald (2000: 402) also notes that "a classifier for "round things" is frequently used as a default classifier [...], the semantic change being fruit $>$ round $>$ generic". For example, in Tariana, an Arawakan language, the suffix -da is the classifier for round objects as well as the generic inanimate classifier (Aikhenvald 1994: 452). Similarly, in its sister language Baniwa, "the classifier 'round' is used for otherwise unclassifiable items; it can also substitute for other classifiers if no particular shape property of the item is focused on" (Aikhenvald 2000: 336).

In RET and TAN, the suffix $-a /-k a$ also has generic semantics, being applied to all inanimate or non-human nouns. However, it does not substitute specific classifiers. In RET inanimate classifiers are obligatory on numerals and optional on demonstratives and adjectives (Strom 1992: 54), whereas in TAN they are obligatory on numerals and demonstratives in deictical function and optional on adjectives (Eraso 2015: 320). In both languages the inanimate classifiers never occur on nouns. As we can see in the examples

\footnotetext{
${ }^{14}$ Chacon (2014: 294) proposes that the change in bound morphemes was $* k{ }^{\prime}>g>\varnothing$.
} 
(42) for RET and (43) for TAN, inanimate nouns are always marked by the neuter suffix - $a$ $k a$, even though their coreferential elements receive inanimate classifiers.

\section{(42) bãẽkaraka-bi rĩpi-a}

three-CLF:1dimen. branch-N

'three branches' (Strom 1992: 55, ex. 182)

(43) $a^{\prime} \phi e-\dot{o} \quad \quad$ óá-ka

other-CLF:round maize-N

'other maize grain' (Eraso 2015: 338)

The only case when a noun occurs without the neuter marker is when it occupies the repeater position, as in (44).

\section{(44) ĩ?rã-pã $\tilde{\boldsymbol{u}}$

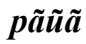 \\ one-RP:hammock hammock \\ 'one hammock' (Strom 1992: 38, ex. 122)}

Given this evidence, we can affirm that the neuter suffix $-a /-k a$ is not a default or generic classifier. It occurs on each inanimate noun, which can belong to any inanimate class. The classification of a noun becomes evident through the markers on coreferential numerals, demonstratives and adjectives. This way, the suffix $-a /-k a$ does not imply that a noun cannot be (or intentionally is not) ascribed to a more specific semantic class. ${ }^{15}$

If we assume that the neuter suffix $-a /-k a$ has originated from the classifier 'round', we have to conclude that RET and TAN once had complex inanimate classification systems, characteristic of ET languages, which are now moving towards gender systems with only one marker for all the inanimates. However, we also have to say that, in the RET and TAN case, the grammaticalization is still an ongoing process, since the usage of the neuter marker has not been extended to all NP elements. The problem of assuming this for RET and TAN is that their inanimate classification systems seem to be more recent developments compared to other ET languages.

According to Grinevald (2000: 1027), the age of a classifying system can be evaluated by the number of classifiers which can still be connected to their lexical sources: "the more numerous the connections, the more recent the system is assumed to be". By this criterion, TAN system cannot be considered an old one, since it includes only four monosyllabic classifiers with unknown lexical origin: - $o$ 'round', $-b i$ 'long', -to 'flat' and $-t i$ 'string' (Eraso 2015: 338). Apart from these, there are 13 disyllabic classifiers, most of them having a transparent lexical origin, and at least 12 repeaters, which by definition are nouns used in the classifier slot (Eraso 2015: 337). In RET the situation is similar (Strom 1992: 54-55). In comparison, Barnes (1990) presents over 90 classifiers (without considering repeaters) in TUY, and lists only 11 of them as related to nouns still used in the language.

${ }^{15}$ Actually, if TAN has something similar to a general classifier, it is exactly the classifier 'round' $-o$, which is attached to the numerals when a person is counting without having specific objects in mind (Eraso 2015: 240). 
Furthermore, if RET and TAN once shared a similar nominal classification system with other ET languages, we would find some very frequent classifiers observable across the family in these two languages. According to Gomez-Imbert (2007: 422-423), the standard list of classifiers in ET languages includes the following items:

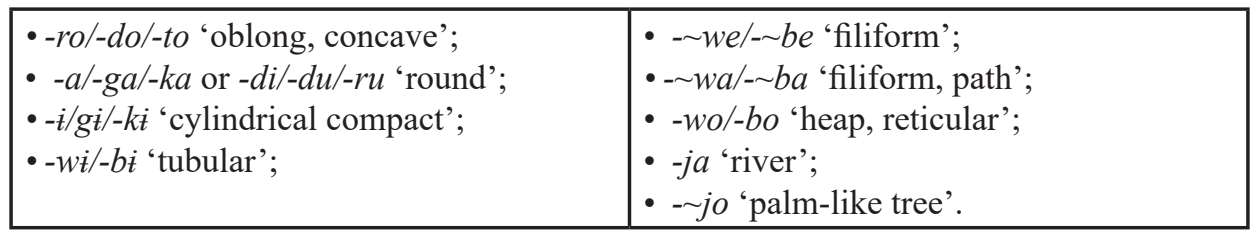

Considering the form and the semantics of these suffixes, none of four RET and TAN monosyllabic inanimate classifiers are their obvious cognates. One good example that shows how RET and TAN nominal classification systems differ from all the others in the ET family is the classifier which Gomez-Imbert glosses as 'cylindrical compact' and which is called 'tree-like' in this paper. ET languages, even those without a - $g a$ cognate (DES and SIR), share the classifier $-t t /-k t /-g t$. It probably originates from the noun meaning 'tree' (yukt in WA'I) and marks nouns for trees and, by extension, other rectilinear objects, as well as some objects with no direct semantic connection to trees (like hammock and fishnet). The monomoraic template and the semantic generalization indicate that in all these languages the suffix is at an advanced stage of grammaticalization and, therefore, is not recent. Differently, the cognate classifier in RET and TAN, - hukí, is clearly a less grammaticalized way, since it marks only nouns for plants and has not suffered a phonetic reduction.

These considerations suggest that RET and TAN nominal classification systems have not been inherited from a common ET source, but are more recent and, therefore, independent developments. It is worth noting that RET and TAN exhibit lexical and morphological borrowings and calques from Yukuna, a neighboring Arawakan language (Rose et al. 2017). It is possible that their classification systems have also emerged under the Yukuna influence. In any case, it seems certain that the RET and TAN neuter suffix - $a$ /$k a$ does not originate from the classifier 'round'. Yet, it is still to be discovered if there is some other sort of diachronic connection between these two morphemes or if they are not cognates at all.

\section{The plural marker of the class 'round'}

In WA'I, the class 'round' is marked by the suffix -poka when the reference is plural. This suffix has no allomorphs and is used both on underived and deverbal nouns (45a) as well as on numerals (45b). There is a variation in pronouncing the first vowel of the suffix: [pohka] $\sim$ pahka] $\sim$ pəhka].

(45) a. senapohka bihsiyepohka > seda-poka pineapple-CLF:round.PL '(many) sweet pineapples'

\section{bisi-ye-poka}

be.sweet-NMLZ.3PL-CLF:round.PL 


\section{b. kopẽpohka tunuñepohka \\ rkope-poka $\quad \sim$ tudu-ye-poka \\ four-CLF:round.PL spin-NMLZ.3PL-CLF:round.PL \\ 'four cars'}

As we have seen in 2.5, the presence of a special plural classifier is not typical for the language. Only two classes, 'round' and 'tree-like', possess different markers in nonplural and plural forms. For all the other classes, the plural is generally marked by addition of the suffix $-d i$ to the classifier. The situation is quite similar in KOT, where the plural classifier 'round' is -phoka. It is also an irregular form, since the countable inanimates are generally pluralized by the suffix -ri (Stenzel 2013: 116).

In TUK, the plural marker of round objects has a similar form: -paga, as shown in (46). However, it is not a single morpheme, being segmented in - $p a$ 'plural' and - $g a$ 'round'. This segmentation is possible, because the suffix - $p a$ also precedes other classifiers ${ }^{16}$ in plural nominal forms, such as -gi 'straight' (47), -ti 'pot', -wi 'tubular and hollow', -wa 'dome-shaped' and -ra 'lake' (Ramirez 1997: 211). In other cases, the plural of inanimates is mostly obtained by addition of the suffix $-r i /-d i /$.

(46) a. $\tilde{u} y \hat{u}-g a$

avocado-CLF:round 'avocado'

(47) a. $\tilde{u} y \hat{u}-g i$

avocado-CLF:straight

'avocado tree' b. ũyu-pa-gá

avocado-PL-CLF:round

'avocados'

c. $\tilde{u} y u-p a-g \dot{́}$

avocado-PL-CLF:straight

'avocado trees' (Ramirez 1997: 214)

Ramirez (1997: 214) suggests that the suffix -pa is an abbreviation of the dummy noun opâ (meaning 'thing'), which always receives a classifier. Even though it is not clear how this noun could have turned into a nominal suffix with the pluralizing function, we will further see that data from other ET languages corroborate this hypothesis.

TUK is not the only ET language, in which the plural suffix - $p a$ combines with several inanimate classifiers, although it never applies to all classifiers. For example, in PIS the - $p a$ precedes a similar set of classifiers: - $g a$ 'round', -gi 'cylindric and broad', $-r i^{17}$ and -vi 'tubular' (De Pérez 2000: 384). All the other classifiers receive the plural suffix /-ri/.

Kinch \& Kinch (2000: 475) note that in YUR "en lo referente a unos pocos los sustantivos inanimados contables, estos se pluralizan al añadir el sufijo plural - $p a$, más un sufijo clasificador". They give nouns from the class 'round' as the example (48). In this language, the pluralizer used with most classifiers is also -ri.

a. dii-ga sõ̃a-ri-ga

rubber-CLF:round be.red-NMLZ.CONT.SG-CLF:round

'the red ball'

\footnotetext{
${ }^{16}$ Ramirez (1997) calls them sufixos de 'forma' (form suffixes).

${ }^{17}$ Not identified in the list of classifiers offered by the author.
} 


\section{b. dii-pa-ga sõán-rẽ-pa-ga}

rubber-PL-CLF:round be.red-NMLZ.CONT.PL-PL-CLF:round

'the red balls'

In TUY, the plural suffix - $p a$ seems to have incorporated the semantics of the class 'round' ${ }^{18}$ As we see in (49), the suffix - $g a$ is restricted to the singular form, whereas the - $p a$ alone is used to mark the plural on a noun from the class 'round'.

(49) a. /sõã-'ri-ga/

be.red-NMLZ-CLF:round

'red ball'

(Barnes \& Malone 2000: 445) b. /sõã-'re-pa/

be.red-NMLZ.PL-CLF:round.PL

'red balls'

Nevertheless, the - $p a$ is also still observable in the suffixes -pári, -páwi and -páwa, which are the respective plural forms of the classifiers - $r i$ ' $p o t$ ', $-w i$ 'hollow interior' and - wa 'shallow container' (Barnes 1990: 280). Inanimate nouns marked by other classifiers receive the suffix $-r i$ in their plural forms.

KAR also has a special plural suffix for the nouns classified as round objects. Whereas other inanimates are pluralized by the suffix - $r i$, the plural of those from the class 'round' is obtained by insertion of the suffix -rupa between the root and the classifier $-a(50)-(52)$.

(50) a. $\tilde{n} a p \tilde{l}-\tilde{a}$

sweet.potato-CLF:round

'sweet potato'

(51) a. peape-a

bullet-CLF:round

'bullet'

(52) a. wirimo- $a$

lime-CLF:round

'lime'

\section{b. ñapi-rupa- $a$}

sweet.potato-PL-CLF:round

'sweet potatos' (Metzger 2000: 53)

b. peape-rupa-a

bullet-PL-CLF:round

'bullets' (Metzger 2000: 61)

b. wirimo-rupa- $a$

lime-PL-CLF:round

'limes' (Metzger 2000: 90)

The suffix -rupa seems to be related to the - $p a$ seen above. It is also likely to have a nominal origin, related to the nouns carupa 'round thing' and rupaz 'body' of the same language. This hypothesis is supported by evidence from other ET languages. In TAT there is a nominal root rúpá- 'unit', which combines with singular inanimate class markers (Gomez-Imbert 2007: 411). In BAR a semantically empty noun ruha is "used with classifiers to refer to an object without naming the object itself" (Jones \& Jones 1991: 58). Given the systematic correspondence between $[\mathrm{h}]$ in BAR and $[\mathrm{p}]$ in other ET languages (Chacon 2014: 285-6), ruha and rupa are clearly cognates.

${ }^{18}$ In this case the suffix - pa may also come from the elision of $/ \mathrm{g} /$ in $/ \mathrm{pa} /+/ \mathrm{ga} /$, which originated /paa/, and the subsequent vowel shortening. A similar process seems to be ongoing in TUK (Chacon 2007: 168, ex. 13a). 
An interesting fact is that, even though DES and SIR seem not to have preserved a $-g a$ cognate, both languages have a special plural morpheme for the nouns classified as round objects. This morpheme is the infix -dupa-in SIR (53) / -dipa- in DES (54), inserted between the nominal root and the classifier $-r u$ 'round'.

a. gó-ru
ball-CLF:round
'ball'

(54) a. go-ru

ball-CLF:round 'ball' b. gó-dupa-ru

ball-PL-CLF:round

'balls' (Criswell \& Brandup 2000: 408)

b. go-dipa-ru

ball-PL-CLF:round

'balls' (Miller 1999: 52, ex. 205)

Miller (1999: 44) also states that "dipa- is a root that can occur with all classifiers to form a noun". In other words, dipa- is used as a dummy noun, functioning similarly to the opâ in TUK. We can note that these forms, as well as rupa from KAR and TAT and ruha from BAR, are probable cognates. These facts support the Ramirez's hypothesis about the origin of the plural suffix - $p a$ from the dummy noun opa in TUK.

There are ET languages which do not have the pluralizer - $p a$ or related suffixes. In TAT, the plural counterpart of the classifier $-a /-k a$ 'round' is the general non-singulative suffix $-e /-j e /-h e .{ }^{19}$ It also classifies generic names of vegetable species, mass nouns, collections and abstract concepts (Gomez-Imbert 2007: 419). There is only one more classifier, -ro/to/- do 'general singular', which is substituted by the -e/-je/-he in plural. All the other classifiers receive the plural marker -ri.

A minority of ET languages do not exhibit a special plural form for the classifier 'round'. For example, in MAK the nouns marked by the suffix - $g a$ receive the regular plural suffix -ri, as shown in (55) - (57). The same seems valid for BAR (58).
a. jeaje-ga
bullet-CLF:round 'bullet'
(56) a. $\tilde{n} a j i-g \tilde{a}$
potato-CLF:round 'potato tuber'

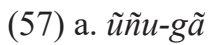 avocado-CLF:round 'avocado'

b. jeaje-ga-ri bullet-CLF:round-PL 'bullets' (Smothermon \& Smothermon 1993: 50)

$$
\begin{aligned}
& \text { b. ñaji-gã-ri } \\
& \text { potato-CLF:round-PL } \\
& \text { 'potato tubers' }
\end{aligned}
$$$$
\text { (Smothermon \& Smothermon 1993: 65) }
$$

$$
\begin{aligned}
& \text { b. ũnu-gã-ri } \\
& \text { avocado-CLF:round-PL } \\
& \text { 'avocados' }
\end{aligned}
$$
(Smothermon \& Smothermon 1993: 99)

\footnotetext{
${ }^{19}$ In WA'I, its cognate is the nominalizer - ye, which derives abstract or mass nouns from verbs.
} 


\author{
$\begin{array}{ll}\text { (58) a. kũbu-a } & \text { b. kũbu-a-ri }\end{array}$ \\ canoe-CLF:round canoe-CLF:round-PL \\ 'canoe' ‘canoes' (Jones \& Jones 1991: 21)
}

Thus, there are only few Eт languages which have no special plural marker for the class 'round'. The majority of these languages use a special morpheme whether to pluralize nouns from the class 'round' and from a few other classes (TUK, PIS, TAT), or to pluralize nouns from the class 'round' exclusively (WA'I, KOT, TUY, KAR).

\title{
7. Conclusion
}

In this paper, the semantic and morphosyntactic properties of the class 'round' in WA'I were described and compared to other ET languages. We have seen that the semantic classes marked by the suffix - $g a$ and its cognates are vast in almost all ET languages, but not identical. We have also stated that, differently from most other classifiers, the - $g a$ and its cognates usually exhibit allomorphy. In particular, WA'I and кот have developed the allomorph -dia/-ria, not found in other ET languages. Probably, this suffix has originated on numerals and on the possession marker yaa by analogy with the sequence - $d i$ 'nominalizer' $+-a$ 'round' present in deverbal nouns.

RET and TAN have the neutral marker $-a /-k a$, a possible cognate of the classifier - $g a$. The comparative data indicates that the neutral marker has not developed from the classifier 'round', but it is not clear if there are some other sort of diachronic relationships between these two morphemes.

Finally, as the data from different ET languages show us, there is a tendency to mark the plural of the nouns from the class 'round' in an irregular way. The WA'I and КОТ suffixes, -poka and -phoka, have no morphological connection to other plural markers in these languages. Perhaps, these forms have been borrowed from a close language (like TUK), which uses the pluralizer - $p a$ preceding the classifier - $g a$. Besides, the comparison between ET languages suggests that the plural suffix -pa and its cognates are related to the dummy noun present in several languages of the family. However, it remains to be discovered how the grammaticalization of the suffix took place.

\section{References}

Aikhenvald, Alexandra. Y (1994). Classifiers in Tariana. Anthropological Linguistics 36(4): 407-465.

Aikhenvald, Alexandra. Y (2000). Classifiers. A typology of noun categorization devices. New York: Oxford University Press.

Balykova, Kristina (2019). Expressão de propriedades no Guató e no Wa'ikhana (MA dissertation in Linguistics). Rio de Janeiro: UFRJ / CLA.

Barnes, Janet (1990). Classifiers in Tuyuca. In Doris L. Payne (ed.). Amazonian linguistics: Studies in Lowland South American languages, pp. 273-292. Austin: University of Texas Press. 
Barnes, Janet; Malone, Terrell (2000). El Tuyuca. In M. S. G. de Pérez e M. L. R. de Montes (eds.). Lenguas de Colombia: Una visión descriptiva, pp. 437-452. Bogotá: Instituto Caro y Cuervo.

Chacon, Thiago Costa (2007). O sistema de classificação nominal do Tukáno. Revista de Estudos e Pesquisas (FUNAI) 4(2): 147-197.

Chacon, Thiago Costa (2012). The phonology and morphology of Kubeo: The documentation, theory, and description of an Amazonian language (PhD thesis in Linguistics). Mānoa: The University of Hawai' $\mathrm{i}$.

Chacon, Thiago Costa (2014). A revised proposal of Proto-Tukanoan consonants and Tukanoan family classification. International Journal of American Linguistics 80(3): 275-322. doi:10.1086/676393

Coutinho-Silva, Thiago (2014). Por dentro dos nomes: A morfologia nominal em Kotiria (Tukano Oriental) ( $\mathrm{PhD}$ thesis in Linguistics). Rio de Janeiro: Universidade Federal do Rio de Janeiro.

Criswell, Linda; Brandrup, Beverly (2000). Un bosquejo fonológico y gramatical del Siriano. In M. S. G. de Pérez e M. L. R. de Montes (eds.). Lenguas de Colombia: Una visión descriptiva, pp. 395-417. Bogotá: Instituto Caro y Cuervo.

De Pérez, María Stella González (2000). Bases para el estudio de la lengua Pisamira. In M. S. G. de Pérez and M. L. R. de Montes (eds.). Lenguas de Colombia: Una visión descriptiva, pp. 373-393. Bogotá: Instituto Caro y Cuervo.

Epps, Patience (2007). Birth of a noun classification system. The case of Hup. In: W. Leo Wetzels (ed.). Language endangerment and endangered languages, pp. 107-127. Leiden: CNWS Publications.

Eraso, Natalia (2015). Gramática tanimuka, una lengua de la Amazonía colombiana ( $\mathrm{PhD}$ thesis in Linguistics). Lyon: Université Lumière - Lyon 2.

Gomez-Imbert, Elsa (1982). De la forme et du sense dans la classification nominale en Tatuyo (Langue Tukano Orientale d'Amazonie Colombienne) (PhD thesis in Linguistics). Paris: Université Sorbonne - Paris IV.

Gomez-Imbert, Elsa (2007). Nominal classification in Tukanoan languages. In W. Leo Wetzels (ed.). Language endangerment and endangered languages: Linguistic and anthropological studies with special emphasis on the languages and cultures of the Andean-Amazonian Border Area, pp. 401-428. Leiden: Leiden University.

Greenberg, Joseph H. (1972). Numeral classifiers and substantival number: Problems in the genesis of a linguistic type. Working papers on language universals 9: 2-39.

Grinevald, Colette (2000). Classifiers. In G. Booij, Ch. Lehmann, J. Mugdan (eds.). Morphology. A handbook on inflection and word formation., pp. 1016-1031. Berlin: Mouton de Gruyter.

Grinevald, Colette; Seifart, Frank (2004). Noun classes in African and Amazonian languages: Towards a comparison. Linguistic Typology 8: 243-285.

IBGE - Instituto Brasileiro de Geografia e Estatística (2010). Censo demográfico 2010. Características gerais dos indígenas. Resultados do universo. Rio de Janeiro: IBGE.

Jones, Wendell; Jones, Paula (1991). Barasano syntax: Studies in the languages of Colombia 2. Dallas: The Summer Institute of Linguistics and The University of Texas at Arlington. 


\section{BALYKOVA - WHAT DO ORANGES AND HAMMERS HAVE IN COMMON?}

Kinch, Rodney; Kinch, Pamela (2000). El Yurutí. In M. S. G. de Pérez and M. L. R. de Montes (eds.). Lenguas de Colombia: Una visión descriptiva, pp. 469-487. Bogotá: Instituto Caro y Cuervo.

Metzger, Ronald G. (2000). Marĩ yaye mena carapana, yaia yaye mena español macãrĩcã tuti (carapana español, diccionario de 1000 palabras). Santafé de Bogotá: Editorial Buena Semilla.

Miller, Marion (1999). Desano grammar. Studies in the languages of Colombia 6. The Summer Institute of Linguistics and The University of Texas at Arlington.

Preciado, Iveth Patricia Rodríguez (2018). Aspectos de la morfología nominal y verbal de la lengua Pisamira: Una lengua de la familia Tucano Oriental del Noroeste Amazónico (MA dissertation in Linguistics). Brasília: UnB.

Ramirez, Henri (1997). A fala Tukano dos Ye’pâ-Masa. Tomo 1. Gramática. Manaus: Inspetoria Salesiana Missionária da Amazônia, CEDEM.

Rose, Françoise; Lemus Serrano, Magdalena; Eraso, Natalia; Chacon, Thiago. (2017). A new look into ArawakTukanoan contact: the Yukuna-Tanimuka bidirectional hypothesis. SSILA Annual Meeting, Austin.

Smothermon, Jeffrey R.; Smothermon, Josephine H. (1993). Masa ye, gawa ye rãca ãmara tuti (macuna español, diccionario de 850 palabras). Santafé de Bogotá: Editorial Alberto Lleras Camargo.

Smothermon, Jeffrey R.; Smothermon, Josephine H.; Frank, Paul S. (1995). Bosquejo del Macuna. Santafé de Bogotá: Associación [sic] Instituto Lingüístico de Verano. Available at: https://www.sil.org/resources/ $\underline{\operatorname{archives} / 18998}$

Stenzel, Kristine (2013). A reference grammar of Kotiria (Wanano). Lincoln: University of Nebraska Press.

Stenzel, Kristine; Cezario, Bruna (2019). Wa'ikhana: Wehsepu buude wehẽgu esamii emo sañuduhkugu'u tu'osua't. Revista LinguíStica, 15(1): 384-417.

Strom, Clay (1992). Retuarã syntax. Studies in the languages of Colombia 3. The Summer Institute of Linguistics and The University of Texas at Arlington.

Recebido: $23 / 4 / 2019$

Versão revista e corrigida: 17/8/2019

Aceito: 20/8/2019. 